\title{
KUALITAS FISIK ORGANOLEPTIK LIMBAH TAUGE KACANG HIJAU YANG DIFERMENTASI MENGGUNAKAN Trichoderma harzianum DENGAN LEVEL YANG BERBEDA
}

\author{
The Physical Quality of Organoleptic Waste Bean Sprout Differented using Trichoderma harzianum \\ with Different Levels
}

\author{
Riskha Ayuk Rihadini, S. Mukodiningsih, S. Sumarsih
}

Department of Animal Husbandry, Faculty of Animal Husbandry and Agriculture, Universitas Diponegoro

Jl. Prof. H. Soedarto, SH, Tembalang, Kota Semarang Kode Pos 50275

email : riskhaayuk@gmail.com

\begin{abstract}
The objective of this research is to test the physical quality of organoleptic including of the color, smell, texture and $\mathrm{pH}$ of fermented bean sprouts using Trichoderma harzianum in different level. This research consists of two phase. The first phase is the process of fermentation of green bean sprouts waste that divided into 4 treatments that is the addition of Trichoderma harzianum at $0 \%, 2 \%, 4 \%$ and $6 \%$ level of 4 replications. The second phase of research is to conduct organoleptic test in covering of the color, smell, texture and $p H$ of fermented bean sprouts waste using Trichoderma harzianum in different level. The material used waste bean sprouts, Trichoderma harzianum, aquades. The data obtained at if statistically using $R A L$. The result data of the research is tested by $F$ test, if there is effect of treatment then proceed with Duncan test at 5\% level. The results showed 2\% Trichoderma harzianum giving the best pH 5,18. Trichoderma harzianum 6\% gives the best color of green brown, texture rather crumbs and acid smells.
\end{abstract}

Keywords:Fermented, Bean Sprouts, Organoleptic, Trichoderma harzianum

\section{PENDAHULUAN}

Pakan merupakan salah satu faktor yang sangat mempengaruhi produktivitas ternak.Kualitas maupun kuantitas pakan yang menurun, dapat menurunkan produksi ternak, sehingga perlu mencari pakan alternatif yang potensial, murah, tidak bersaing dengan kebutuhan manusia dan mudah diperoleh.Sisa hasil produksi pertanian atau limbah pertanian umumnya kurang dimanfaatkan sebagai pakan karena nutrisinya yang rendah.Salah satu limbah pertanian yang dapat dimanfaatkan sebagai pakan yaitu limbah tauge kacang hijau.

Limbah tauge kacang hijau merupakan sisa produksi tauge yang terdiri dari kulit kacang hijau dan pecahan-pecahan tauge (Christiana, 2012). Produksi kacang hijau secara nasional sekitar 271.463 ton pada tahun 2015 dan berpeluang untuk menghasilkan limbah tauge sebesar 407.194,5 ton. Setiap $1 \mathrm{~kg}$ kacang hijau menghasilkan $5 \mathrm{~kg}$ tauge, sedangkan 100 gram berupa kulit tauge kacang hijau (Yulianto, 2010). Limbah tauge kacang hijau mengandung protein kasar (PK) 13,67\%, lemak kasar (LK) $1,17 \%$, serat kasar (SK) $49,44 \%$ dan TDN $64,65 \%$ (Yulianto, 2010). Limbah tauge kacang hijau memiliki kandungan serat kasar yang tinggi yaitu $49,44 \%$. Pakan yang berserat kasar tinggi tidak bisa diberikan secara langsung pada unggas karena didalam saluran pencernaan unggas tidak terdapat mikroba yang mampu mencerna serat kasar tersebut, sehingga memerlukan perlakuan fermentasi untuk menurunkan kadar serat kasar (Pamungkas, 2011).

Fermentasi merupakan proses pemecahan senyawa organik menjadi senyawa yang lebih sederhana dengan melibatkan mikroorganisme. Proses fermentasi bertujuan untuk menurunkan serat kasar, meningkatkan nilai nutrisi, dan meningkatkan daya cerna. Mikroorganisme yang digunakan dalam penelitian yaitu Trichoderma harzianum. Kapang Trichoderma harzianum tergolong mikroorganisme selulolitik yang menghasilkan enzim selulase berfungsi untuk menurunkan serat kasar. Proses fermentasi menggunakan Trichoderma harzianum dapat memecah molekul yang kompleks menjadi molekul yang sederhana sehingga bahan pakan memiliki tekstur remah.Trichoderma harzianum dapat hidup dalam kondisi $\mathrm{pH}$ asam berkisar antara 5-7, sehingga bahan pakan yang difermentasi 
memiliki bau cenderung asam.Trichoderma harzianum memiliki miselium hijau sehingga bahan pakan yang difermentasi cenderung memiliki warna hijau.

Penelitian bertujuan untuk mengkaji pengaruh Trichoderma harzianum sebagai starter untuk fermentasi limbah tauge kacang hijau dan pengaruhnya terhadap kualitas fisik organoleptik meliputi warna, bau, tekstur dan $\mathrm{pH}$ pada limbah tauge kacang hijau yang difermentasi dengan Trichoderma harzianum pada level yang berbeda. Manfaat penelitian adalah memberi informasi kualitas fisik organoleptik (warna, tekstur, bau dan $\mathrm{pH}$ ) pada limbah tauge kacang hijau yang difermentasi dengan Trichoderma harzianum pada level yang berbeda. Hipotesis penelitian terdapat pengaruh level starter Trichoderma harzianum yang berbeda terhadap kualitas fisik organoleptik limbah tauge kacang hijau.

\section{MATERI DAN METODE}

Penelitian dilaksanakan pada bulan November-Desember 2016 di Laboratorium Teknologi Pakan, Fakultas Peternakan dan Pertanian, Universitas Diponegoro, Semarang.

\section{Materi}

Materi yang digunakan dalam penelitian ini meliputi limbah tauge sebanyak 1600 gram, Trichoderma harzianum dan aquades. Peralatan yang digunakan antara lain oven, timbangan analitik, $\mathrm{pH}$ meter, baskom, plastik, lakban, dan lembar penilaian organoleptik.

\section{Metode}

Penelitian dibagi menjadi 2 tahap: tahap persiapan dan tahap pelaksanaan. Tahap persiapan yaitu mengumpulkan limbah tauge, selanjutnya limbah tauge dikering udarakan kemudian ditimbang hingga diperoleh 1600 gram, kemudian di tambahkan molasses $0,16 \%$ serta aquades sebanyak $60 \%$, masukkan bahan pakan kedalam autoklaf untuk sterilisasi dengan suhu $121^{\circ} \mathrm{C}$ selama 15 menit,bahan pakan yang telah disterilisasi dibagi menjadi 4 perlakuan dengan menggunakan Trichoderma harzianum sesuai perlakuan $0 \%, 2 \%, 4 \%$ dan $6 \%$. Campuran tersebut kemudian dimasukkan kedalam plastik yang sudah di lubangi dengan kondisi anaerob fakultatif. Bahan tersebut kemudian diperam selama 4 hari. Fermentasi Trichoderma harzianum optimum pada lama pemeraman 4 hari (Mahmilia, 2005).

Tahap pelaksanaan yaitu limbah tauge yang ditelah diperam selama 4 hari, dilakukan uji organoleptik meliputi warna, bau, tekstur dan
$\mathrm{pH}$ dan di skoring oleh panelis terlatih sebanyak 15 orang. Panelis terlatih terdiri dari 8-12 orang yang memiliki kepekaan sensori cukup tinggi, tetapi tidak sama dengan kepekaan sensori panel terbatas (Lawless dan Heymann, 1999). Penelitian dilakukan menggunakan rancangan acak lengkap (RAL) pola searah dengan 4 perlakukan (T0, T1, T2, T3) dan 4 ulangan (U1, U2, U3, U4).

\section{Peubah yang Diamati}

1. Warna

Panelis mengamati perbedaan warna limbah tauge yang difermentasi menggunakan Trichoderma harzianum pada level $0 \%, 2 \%, 4 \%, 6 \%$. Menurut Ariyanti (2015) warna tongkol jagung yang difermentasi menggunakan Trichoderma harzianum diperoleh warna hijau kekuningan.

2. Bau

Panelis mengamati perbedaan bau limbah tauge yang difermentasi menggunakan Trichoderma harzianum pada level 0\%, 2\%, 4\%, 6\%. Menurut Ariyanti (2015) bau tongkol jagung yang difermentasi menggunakan Trichoderma harzianum diperoleh bau asam.

3. Tekstur

Panelis mengamati perbedaan tekstur limbah tauge yang difermentasi menggunakan Trichoderma harzianum pada level 0\%, 2\%, 4\%, 6\%. Menurut Ariyanti (2015) tekstur tongkol jagung yang difermentasi menggunakan Trichoderma harzianum diperoleh tekstur lembut.

4. $\mathrm{pH}$

$\mathrm{pH}$ sebelum dan sesudah limbah tauge yang difermentasi menggunakan Trichoderma harzianum pada level 0\%, 2\%, 4\%, 6\%. Menurut Jaelani dkk.(2015) pH pelepah sawit yang difermentasi menggunakan Trichoderma harzianum diperoleh pH 5-7.

\section{HASIL DAN PEMBAHASAN}

\section{Pengaruh Fermentasi Trichoderma harzianum terhadap Warna Limbah Tauge Kacang Hijau dengan Level yang Berbeda}

Pengamatan warna hasil fermentasi limbah tauge kacang hijau dapat disajikan pada Tabel 1. Hasil analisis ragam menunjukkan 
bahwa perlakuan level starter Trichoderma harzinum berpengaruh nyata $(\mathrm{p}<0,05)$ terhadap warna limbah tauge kacang hijau. Hasil uji wilayah Duncan menunjukkan perlakuan T0 tidak berbeda nyata dengan T1, T2, T3. T1 tidak berbeda nyata dengan T0, T2, T3, T2. T2 tidak berbeda dengan T0, T1, T3. T3 tidak berbeda nyata $\mathrm{T} 0, \mathrm{~T} 1$, dan $\mathrm{T} 2$.

Tabel 1. Skor Warna Limbah Tauge Kacang Hijau yang Difermentasi Menggunakan Trichoderma harzianum pada Level yang Berbeda

\begin{tabular}{cccccc}
\hline \hline Level & \multicolumn{5}{c}{ Perlakuan } \\
\cline { 2 - 5 } $\begin{array}{c}\text { starter } \\
(\%)\end{array}$ & 0 & 2 & 4 & 6 & $\begin{array}{c}\text { Rata- } \\
\text { rata }\end{array}$ \\
\hline $\mathrm{U} 1$ & 1,80 & 1,50 & 1,50 & 2,40 & 1,80 \\
$\mathrm{U} 2$ & 1,90 & 1,50 & 1,40 & 2,40 & 1,80 \\
$\mathrm{U} 3$ & 1,90 & 1,60 & 1,90 & 2,40 & 1,95 \\
$\mathrm{U} 4$ & 1,80 & 1,50 & 1,80 & 2,40 & 1,88 \\
\hline Rata- & $1,85^{\mathrm{ab}}$ & $1,53^{\mathrm{a}}$ & $1,65^{\mathrm{ab}}$ & $2,40^{\mathrm{a}}$ &
\end{tabular}

\begin{tabular}{cl} 
rata & \\
\hline Keterangan: & Superskrip dengan huruf kecil \\
& yang berbeda pada baris yang \\
& sama menunjukkan perbedaan \\
& nyata $(\mathrm{p}<0,05)$
\end{tabular}

Penambahan starter Trichoderma harzianum $6 \%$ pada lama pemeraman 4 hari menghasilkan warna terbaik yaitu hijau kecoklatan. Hal tersebut tidak sesuai dengan pendapat Ariyanti (2015) bahwa warna terbaik fermentasi tongkol jagung dengan Trichoderma harzianum yaitu warna hijau kekuningan. Perubahan warna hijau kekuningan tersebut merupakan efek dari penambahan starter Trichoderma harzianum, hal ini disebabkan karena adanya kumpulan konidia pada ujung hifa kapang tersebut. Perubahan warna hijau kecoklatan tersebut merupakan pengaruh dari limbah tauge yang disterilisasi didalam autoklaf berubah warna dari hijau menjadi hijau kecoklatan. Suhu yang tinggi selama proses fermentasi menyebabkan reaksi maillard sehingga warna limbah tauge kacang hijau berwarna cokelat. Hal tersebut sesuai pendapat Gayang (2013) bahwa suhu yang tinggi selama proses fermentasi dapat menyebabkan perubahan warna fermentasi sebagai akibat terjadinya reaksi maillard yang berwarna kecoklatan. Menurut Dedin et. al. (2006) bahwa reaksi maillard adalah reaksi yang terjadi antara gugus amino dari suatu asam amino bebas, residu rantai peptide atau protein dengan gugus karbonil dari suatu karbohidrat apabila keduanya dipanaskan atau tersimpan dalam waktu yang relatif lama.

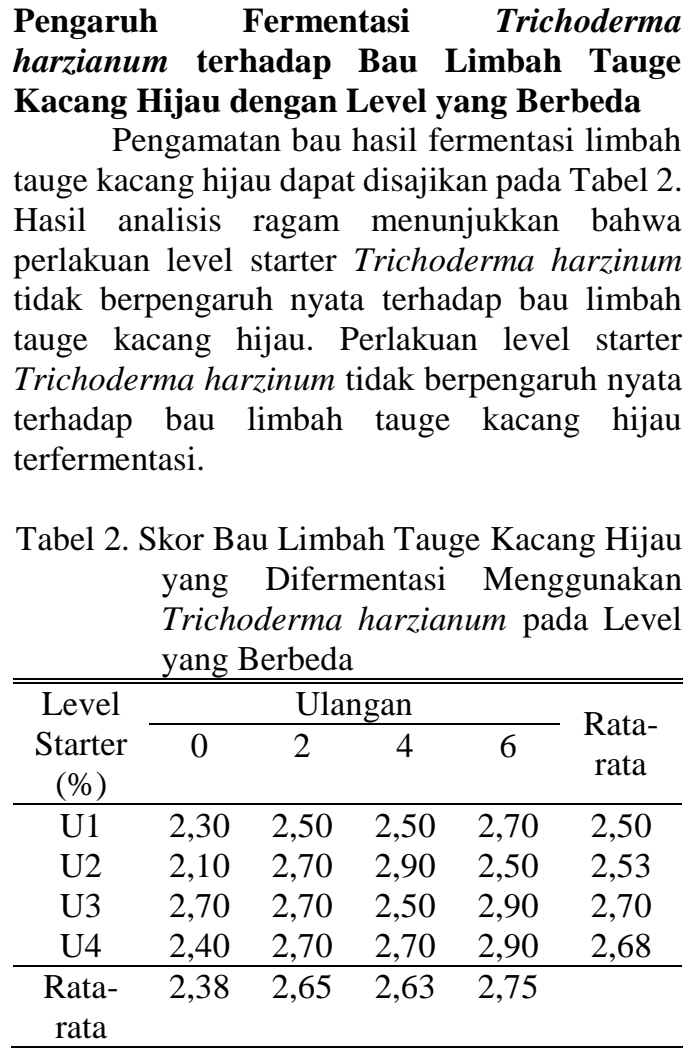

Hal ini menunjukkan bahwa penggunaan level starter hingga taraf $6 \%$ tidak menunjukkan skor bau yang berbeda meskipun bau limbah tauge fermentasi tergolong baik. Rata-rata skor bau limbah tauge kacang hijau masing-masing perlakuan T0, T1, T2, dan T3 berturut-turut adalah 2,38, 2,65, 2,63, dan 2,75 tergolong memiliki bau agak asam. Menurut Ariyanti (2015) bahwa bau terbaik fermentasi tongkol jagung dengan Trichoderma harzianum yaitu bau asam. Menurut Wahyudi et. al. (2012) bahwa pertumbuhan yang lebih cocok Trichoderma harzianum pada kondisi asam atau pH rendah berkisar antara 5-7. Hal ini sesuai pendapat Mulyono et. al. (2009) bahwa mikrobia membutuhkan kondisi keasaman medium yang spesifik untuk keberlangsungan hidup dan pertumbuhannya. Limbah tauge kacang hijau mengalami perubahan bau agak asam. Hal tersebut sesuai pendapat Wijaya et. al. (2015) bahwa bau daun cengkeh hasil fermentasi mengalami perubahan bau khas fermentasi yang agak menyengat. Bau khas fermentasi tersebut diduga berasal dari asam sitrat.

\section{Pengaruh Fermentasi Trichoderma harzianum terhadap Tekstur Limbah Tauge Kacang Hijau dengan Level yang Berbeda}

Pengamatan tekstur hasil fermentasi limbah tauge kacang hijau dapat disajikan pada 
Tabel 3. Perlakuan level starter Trichoderma harzinum tidak berpengaruh nyata terhadap tekstur limbah tauge kacang hijau terfermentasi. Hal ini menunjukkan bahwa penggunaan level starter hingga taraf $6 \%$ belum optimal mengubah tekstur fermentasi yang ditunjukkan dengan tekstur agak remah.

Tabel 3. Skor Tekstur Limbah Tauge Kacang Hijau yang Difermentasi Menggunakan Trichoderma harzianum pada Level yang Berbeda

\begin{tabular}{cccccc}
\hline \hline \multirow{2}{*}{$\begin{array}{c}\text { Level } \\
\text { Starter } \\
(\%)\end{array}$} & 0 & 2 & 4 & 6 & $\begin{array}{c}\text { Rata- } \\
\text { rata }\end{array}$ \\
\cline { 2 - 6 } & & & & & \\
\hline $\mathrm{U} 1$ & 3,30 & 3,00 & 3,10 & 3,40 & 3,20 \\
$\mathrm{U} 2$ & 3,10 & 3,20 & 3,10 & 3,10 & 3,13 \\
$\mathrm{U} 3$ & 3,20 & 3,00 & 3,10 & 3,30 & 3,15 \\
$\mathrm{U} 4$ & 2,90 & 3,10 & 3,10 & 3,40 & 3,13 \\
\hline $\begin{array}{c}\text { Rata- } \\
\text { rata }\end{array}$ & 3,13 & 3,08 & 3,10 & 3,30 & \\
\hline
\end{tabular}

Rata-rata skor tekstur limbah tauge masing-masing perlakuan T0, T1, T2, dan T3 berturut-turut adalah $3,13,3,08,3,10$, dan 3,30 tergolong memiliki tekstur agak remah. Menurut Gani (2013) bahwa tekstur fermentasi bahan pakan dengan Trichoderma harzianum bertekstur remah karena miselium Trichoderma yang berwarna kehijauan telah berkembang pada bahan pakan dan terjadi perombakan struktur kompleks menjadi struktur yang lebih sederhana secara biologis oleh Trichoderma harzianum. Hal ini sesuai pendapat Pamungkas (2011) bahwa proses fermentasi mampu memecah komponen-komponen yang komplek menjadi lebih sederhana sehingga mudah dicerna. Perombakan struktur kompleks didegradasi oleh enzim selulase. Menurut Ariyanti (2015) bahwa tekstur tongkol jagung yang difermentasi dengan Trichoderma harzianum memiliki tekstur remah.

\section{Pengaruh Fermentasi Trichoderma harzianum terhadap pH Limbah Tauge Kacang Hijau dengan Level yang Berbeda}

Pengamatan $\mathrm{pH}$ hasil fermentasi limbah tauge kacang hijau dapat disajikan pada Tabel 4. Hasil analisis ragam menunjukkan bahwa perlakuan level starter Trichoderma harzinum berpengaruh nyata $(\mathrm{p}<0,05)$ terhadap $\mathrm{pH}$ limbah tauge kacang hijau fermentasi. Hasil uji wilayah Duncan menunjukkan perlakuan T0 berbeda nyata lebih tinggi dengan perlakuan T1dan T2, tetapi tidak berbeda nyata dengan T3. Perlakuan T1 berbeda nyata lebih rendah dengan perlakuan $\mathrm{T} 0$, tetapi tidak berbeda nyata dengan T2 dan T3.
Perlakuan T2 tidak berbeda nyata dengan T1 dan $\mathrm{T} 3$, tetapi berbeda nyata lebih rendah dengan T0 dan T3.Perlakuan T3 tidak berbeda nyata dengan T0, T1 dan T2.

Tabel 4. Skor pH Limbah Tauge Kacang Hijau yang Difermentasi Menggunakan Trichoderma harzianum pada Level yang Berbeda

\begin{tabular}{cccccc}
\hline \hline Level & \multicolumn{4}{c}{ Ulangan } \\
\cline { 2 - 5 } $\begin{array}{c}\text { Starte } \\
\mathrm{r}\end{array}$ & 0 & 2 & 4 & 6 & $\begin{array}{c}\text { Rata } \\
\text {-rata } \\
(\%)\end{array}$ \\
\hline $\mathrm{U} 1$ & 5,80 & 5,40 & 5,40 & 5,60 & 5,50 \\
$\mathrm{U} 2$ & 5,40 & 4,70 & 5,20 & 5,50 & 5,20 \\
$\mathrm{U} 3$ & 5,80 & 5,40 & 5,30 & 5,20 & 5,45 \\
$\mathrm{U} 4$ & 6,00 & 5,20 & 5,40 & 5,30 & 5,48 \\
\hline Rata- & 5,75 & 5,18 & 5,33 & $5,40^{\mathrm{a}}$ \\
rata & $\mathrm{a}$ & $\mathrm{b}$ & $\mathrm{b}$ & $\mathrm{b}$ & \\
\hline
\end{tabular}

Keterangan: Superskrip dengan huruf kecil yang berbeda pada baris yang sama menunjukkan perbedaan nyata $(\mathrm{P}<0,05)$

Penambahan starter Trichoderma harzianum $2 \%$ memiliki $\mathrm{pH}$ yaitu 5,18. Menurut Jaelani et. al. (2015) bahwa pH terbaik pelepah sawit yang difermentasi Trichoderma harzianum memiliki $\mathrm{pH}$ 5-7. Hal ini sesuai pendapat Uruilal et. al. (2012) pertumbuhan Trichoderma harzianum optimum membutuhkan media dengan $\mathrm{pH}$ 3-7. Trichoderma harzianum menunjukkan pertumbuhan yang lebih cocok pada kondisi asam dan kapang pada umumnya akan menunjukkan pertumbuhan terbaik pada kondisi asam atau $\mathrm{pH}$ rendah.

Menurut Uruilal et. al. (2012) bahwa pertumbuhan dan perkembangan Trichoderma harzianum dipengaruhi oleh sejumlah faktor di antaranya suhu, cahaya, udara, $\mathrm{pH}$ serta nutrisi seperti karbon, nitrogen dan karbohidrat sederhana. Hal tersebut sesuai pendapat Menurut Ganjar et. al. (2006) bahwa secara umum pertumbuhan jamur dipengaruhi oleh substrat, kadar air, derajat keasaman substrat (pH) dan senyawa kimia dilingkungannya.

\section{SIMPULAN}

Fermentasi limbah tauge kacang hijau menggunakan Trichoderma harzianum dengan level yang berbeda berpengaruh nyata $(\mathrm{p}<0,05)$ meningkatkan kualitas warna dan $\mathrm{pH}$ limbah tauge kacang hijau. Warna terbaik fermentasi limbah tauge kacang hijau didapatkan dari pemberian starter Trichoderma harzianum 6\% memiliki warna hijau kecoklatan. $\mathrm{pH}$ terbaik 
fermentasi limbah tauge kacang hijau didapatkan dari pemberian starter Trichoderma harzianum $2 \%$ yaitu 5,18 dengan standar $\mathrm{pH}$ fermentasi Trichoderma harzianum yaitu 5-7.

\section{DAFTAR PUSTAKA}

Ariyanti.2015. Kandungan Bahan Organik dan Protein Kasar Tongkol Jagung (Zea mays) yang Diinokulasi dengan Fungi Trichoderma sp. pada Lama Inkubasi yang Berbeda. Fakultas Peternakan. Universitas Hasanuddin. Makasar. (Skripsi).

Christiana, N. 2012. Efisien dan Kecernaan Serat Ransum Mengandung Limbah Tauge pada Kelinci Lokal Jantan Masa Pertumbuhan. Fakultas Peternakan. Institut Pertanian Bogor. (Skripsi).

Dedin, F. R., D. Fardiaz., A. Apriyantono., dan N. Andarwulan. 2006. Isolasi dan karakterisasi melanoidin kecap manis dan peranannya sebagai antioksidan. J. Teknologi dan Industri Pangan. 17 (3) : 204-2013

Ganjar, I., Wellyzar, S dan O. Ariyani. 2006. Mikologi Dasar dan Terapan. Yayasan Obor Indonesia. Jakarta.

Gayang, F. 2013. Konversi Lignoselulosa Tandan Kosong Kelapa Sawit menjadi Gula Pereduksi menggunakan Enzim Xilanase dan Selulase Komersial. Fakultas Matematika dan Ilmu Pengetahuan Alam. Institut Pertanian Bogor, Bogor. (Skripsi)

Jaelani, A., S. Dharmawati., dan B. Lesmana.2015. Pengaruh Lama
Penyimpanan Hasil Fermentasi Pelepah Sawit oleh Trichoderma sp Terhadap Kandungan Selulosa dan Hemiselulosa. J. Ziraa'ah. 40 (2) : 165-174.

Mahmilia, F. 2005. Perubahan nilai gizi tepung enceng gondok fermentasi dan pemanfaatannya sebagai ransum ayam pedaging. J. Ilmu Ternak Veteriner. 10 (2) : 90-95.

Mulyono, A. M. Y., M. N. Cahyanto., Zuprizal., dan Z. Bachruddin. 2009. Fermentasi onggok menggunakan mutan Trichodermauntuk produksi selulase. J. Agritech. 29 (2) : 53-58

Pamungkas, W. 2011.Teknologi fermentasi, alternatif solusi dalam upaya pemanfaatan bahan pakan lokal. J. Media Akuakultur 6 (1) : 43-48

Uruilal, C., A. M. Kalay., E. Kaya., dan A. Siregar. 2012. Pemanfaatan kompos sagu, sekam dan dedak sebagai media perbanyakan agen hayati Trichoderma harzianum.J. Agrologia. 1 (1) : 21-30

Wahyudi, P., U. Suwahyono., dan S. Mulyati. 2012. Pertumbuhan Trichoderma harzianum pada Medium yang Mengandung Xilan. Badan Pengkajian dan Penerapan Teknologi.Universitas Negeri Jakarta. Hal 1-7.

Yulianto, J. 2010. Pengaruh Penggunaan Kulit Kecambah Kacang Hijau dalam Ransum Terhadap Kecernaan Bahan Kering dan Organik pada Kelinci Keturunan Vlaams reus Jantan. Fakultas Pertanian. Universitas Sebelas Maret. Surakarta. (Skripsi). 